\title{
CYRIL A METOD V KULTÚRE DOLNOZEMSKÝCH SLOVÁKOV
}

\author{
Cyril and Methodius in the Culture of Lowland Slovaks
}

\author{
Jaroslav Čukan - Boris Michalík
}

DOI: $10.17846 /$ CL.2021.14.1.146-157

\begin{abstract}
UKAN, Jaroslav - MICHALÍK, Boris. Cyril and Methodius in the Culture of Lowland Slovaks. The Thessalonian brothers are known among Slovak and Slavonic people as translators of the Scriptures into a language comprehensible to the people in the Great Moravian Empire and to other Slavs. Their evangelical mission and the creation of a language of worship has a Christian, cultural-emancipatory, ethno-identifying and at the same time ethno-differentiating character in the connection with Slavs as well as in relation to nations from other language groups or families. Slovakia adequately respects these personalities and their merits: St Cyril and Methodius Day celebrated on 5th July is dedicated to them, and this day is also the Day of Foreign Slovaks. These missionaries are thus in the centre of a contextual circle: Slavs - Slovaks in Slovakia and abroad - Cyril and Methodius - ethno-cultural identity. In researching individual components of cultural potential of the Lowland Slovaks, in the last three decades we have found much evidence to show how these personalities became part of the cultural of the Lowland Slovaks: as part of the church history, Christian theory and cultural history; memorial days in Christian calendars; providing the names for parishes and churches; the object of school teaching; Slavic and Slovak reciprocity; specific ways of commemorating the Thessalonian brothers through the visual arts, institutional celebrations and forgiveness as specific ecclesiastical, social and cultural events at the level of local and Christian communities and institutions; roads in the footsteps of Cyril and Methodius leading to Slovakia and to Nitra and deepening the companionship with the mother nation. The aim of the paper is to point out the interdisciplinary contexts of the study of their reflections in the Slovaks living in Lowland.
\end{abstract}

Keywords: interpretation of culture, the Unity of Slavic People, Slovaks in their homeland and Lowland Slovaks, cultural history, ethnocultural identity

Solúnski bratia sú vo vedomí slovenského a slovanského sveta známi predovšetkým ako prekladatelia Svätého písma do jazyka zrozumitelného vel'komoravskému ludu aj iným Slovanom. Ich evanjelizačná misia a vytvorenie bohoslužobného jazyka má charakter krestanský, kultúrno-emancipačný, etnoidentifikačný a zároveň etnodiferenciačný v intenciách Slovanstva aj v širších súvislostiach. Slovensko si tieto osobnosti a ich zásluhy primerane váži už aj preto, lebo sú bytostne späté s územím dnešného Slovenska. Slovanský stredoeurópsky národ, ktorý tvoria v prevažnej väčšine krestania západného aj východného obradu, im venoval štátny sviatok svätého Cyrila a Metoda; 5. júl je zároveň aj Dňom zahraničných Slovákov (zhoda v dátume nie je náhodná). Vierozvestcovia sú tak v strede internacionálnych aj ekumenických kruhov: Slovania - Slováci na Slovensku aj za hranicami - Cyril a Metod - etnokultúrna identita; krestania západného rítu (rímskokatolíci, reformovaní krestania viacerých vierovyznaní) - východného rítu - Cyril a Metod. Ich význam spočíva - prostredníctvom viery - aj vo vytváraní vzájomnosti Slovanov 
s neslovanskými (románski Rumuni) a dokonca aj s inými ako indoeurópskymi národmi (uralsko-altajskí Mad’ari). Sú to v odborných - antropologických aj náboženských - kruhoch také rozmery ich významu, ktoré doteraz vo vedeckej spisbe neregistrujeme (možno kvôli nášmu odlišnému predmetu vedeckého záujmu).

Pri výskume jednotlivých súčastí kultúrneho potenciálu dolnozemských Slovákov sme sa v posledných troch desatročiach postupne stretli s viacerými reflexiami týchto osobností: ako súčasti dejín cirkvi, krestanského učenia a kultúrnej histórie; pamätných dní v krestanských kalendároch; pomenovávania farností a kostolov; objektov školskej výučby; slovanskej a slovenskej vzájomnosti; špecifických spôsobov pripomínania si solúnskych bratov prostredníctvom výtvarného umenia, inštitucionálnych osláv a odpustov ako špecifických cirkevných, spoločenských a kultúrnych podujatí na úrovni lokálnych a krestanských spoločenstiev a inštitúcií1; ciest po stopách Cyrila a Metoda na Slovensko a do Nitry a prehlbovania spolupatričnosti s materským národom.

Štúdium cyrilo-metodskej tradície nie je primárnym cielom našej vedeckovýskumnej práce. V rámci výskumu a štúdia spôsobu života slovenských minoritných spoločenstiev južne od hraníc dnešného Slovenska sme sa v rôznych súvislostiach stretli aj s rôznymi kontextami odkazu svätých Cyrila a Metoda. V slovanskom Chorvátsku si pripomína ich misiu rímskokatolícka cirkev kvôli ich christianizačným zásluhám, ktoré vyzdvihoval biskup Josip Juraj Strossmayer (Tomljanovich 2001, 278-284). Pomenované sú podla nich niektoré rímskokatolícke farnosti (chorv. župa), 5. júla sú uvedení v katolíckom kalendári; Srbi si ich ctia, okrem krestanského rozmeru, ako tvorcov základu ich písma²; pravoslávni Rumuni na nich nezabúdajú v súvislosti $\mathrm{s}$ ich pôvodom vo Východorímskej ríši a v kontexte s východným obradom - v pravoslávnych chrámoch sú súčastou ikonostasov, objavujú sa aj samostatné ikony; v Mad’arsku sú stotožňovaní s Blatnohradom, kde sa zastavili na svojej ceste do Ríma ${ }^{3}$ a túto udaloste pripomína osobitný pamätník. Cyrilo-metodskú tradíciu zachovávajú a rozvíjajú najmä Slováci aj napriek tomu, že mad’arské obyvatel'stvo bolo christianizované aj vd’aka bezprostredným kontaktom a susedstvu so slovanským obyvatel'stvom.

Cielom príspevku je poukázat na reflexiu týchto osobností u Slovákov na Dolnej zemi, na interdisciplinárne, ekumenické, interetnické a národno-emancipačné kontexty vierozvestcov a ich diela. Chceme poukázat na okolnosti a súvislosti vedomia príslušníkov slovenských minoritných spoločenstiev a ich vztahu k cyrilo-metodskej tradícii v jednotlivých dolnozemských štátoch podla ich politickej orientácie, vztahu $\mathrm{k}$ menšinám, prevládajúceho vierovyznania a etnokultúrnej príslušnosti majoritného obyvatel’stva. Nadväzujúc na doterajšie mapovanie a hodnotenie kultúrneho potenciálu dolnozemských Slovákov sa snažíme vytvorit’ obraz o stave cyrilo-metodskej tradície a jej prejavov u Slovákov v štyroch štátoch na konci 2. desatročia 21. storočia.

\section{Metodické východiská}

Naše štúdium kultúry Slovákov na Dolnej zemi trvá od prvej polovice 90. rokov minulého storočia. V rámci národopisných vedecko-výskumných táborov, organizovaných Výskumným ústavom Slovákov v Mad’arsku v Békešskej Čabe sme navštívili najznámejšie aj menej početné slovenské spoločenstvá na celom území Mad’arska; s rumunskými, srbskými a chorvátskymi Slovákmi sme sa pravidelne stretávali pri výskume v slovenských enklávach a diaspórach. Po vydaní viacerých

Porovnaj so: Šusteková 2012.

Bližšie napr. Zozulak 2019.

3 Blatnohrad bol sídlom slovanského kniežata Pribinu po jeho vyhnaní z Nitry po roku 833 a neskôr i jeho syna Kocela. Sv. Cyril a Metod sa v roku 867 cestou do Ríma zastavili pri kniežacom dvore Kocela v Zalavári, kde dlhšie pobudli (Ivanič - Lukáčová 2015, 655; Szőke 2010, 9-52). 
monografií minoritných lokálnych spoločenstiev sa kolektív pracovníkov Katedry manažmentu kultúry a turizmu Filozofickej fakulty UKF v Nitre podielal v ostatných rokoch (2016 - 2020) na riešení vedeckovýskumného projektu, zameraného na mapovanie a hodnotenie kultúrneho potenciálu dolnozemských Slovákov. V prvom pláne neboli cielom výskumu otázky súvisiace s misiou a dielom svätých Cyrila a Metoda, no postupne sa objavovali vo viacerých kontextoch. Ak sme sa rozhodli venovat tejto problematike väčšiu pozornost', potrebné bolo zhromaždit viac informácií, ako sme o nej získali v rámci terénnych výskumov (rozhovory s informátormi, zúčastnené aj nezúčastnené pozorovanie, vizuálna dokumentácia, štúdium v štátnych aj cirkevných archívoch). Písaniu štúdie predchádzalo niekol'komesačné získavanie konkrétnych údajov od spolupracovníkov a známych, z radov duchovných rôznych cirkevných spoločenstiev, z kultúrnych spolkov a inštitúcií, od menšinových samospráv, členov Matice slovenskej, pedagógov a lektorov zo základných škôl, lýceí aj z univerzít, od našich bývalých študentov. Každému sme sformulovali a elektronicky poslali originálny dotazník s konkrétnymi otázkami podla štátu (Mad’arsko, Rumunsko, Srbsko, Chorvátsko), profesie a statusu respondenta. Ak nám niektorí z oslovených neodpovedali, snažili sme sa získat sprostredkované údaje. Možno konštatovat', že terénnym výskumom a následnými špecifickými formami získavania údajov sme zhromaždili rôznorodý, bohatý materiál k dotvoreniu obrazu o živote a názoroch dolnozemských Slovákov na Cyrila a Metoda. Doplnili sme ich štúdiom niekolkých starších aj súčasných publikovaných zdrojov ${ }^{4}$ a doteraz nepublikovanou príležitostnou kázňou evanjelického farára Jána Vidu z Báčskeho Petrovca. Za povšimnutie isto stojí kázeň Reč Chrámová... bánhedešského evanjelického farára Jána Kutlíka ml., ktorú predniesol pri príležitosti 1000. výročia príchodu sv. Cyrila a Metoda a vydal ju aj tlačou spolu s piesňou Jána Kutlíka st. Sláwospew k tisjcročneg pamiatke Cirylo-Methodegskeg. Označuje ich ako apoštolov Slovanstva a ich pamiatku ako tisícročnú krestansko-slovenskú. Pripomenul, že podobná aktivita sa už predtým konala v nadlackom evanjelickom cirkevnom zbore. ${ }^{5}$ Hájil ekumenizmus a vyzdvihol národnú jednotu. ${ }^{6}$ Príspevok Anny Margaréty Valentovej vo vojvodinskom časopise Slovenská literatúra ${ }^{7}$ nám pripomenul dvojmesačník Proglas, ktorý vydáva Slovenský evanjelický a. v. cirkevný zbor vo Vojlovici. Pripravujú ho zborový farár Branislav Kulík s katechétkou Alenou Gajanovou-Kulíkovou. Názov Proglas zvolili zámerne, aby veriacim pravidelne, nielen $\mathrm{v}$ rámci kázní pri príležitosti spomienok na ich príchod, pripomínali v slovenskom jazyku ich význam pre krestanstvo a vzdelanost. ${ }^{8}$ Krestanské, národnouvedomovacie, kultúrne, vydavatel'ské,

4 Reflexii kultúrneho dedičstva sv. Cyrila a Metoda na Slovensku sa prostredníctvom podobnej metodiky venoval Hetényi (2019).

5 „Zvláštneho ešte spomenutia zasluhuje, že i evanj. bratia naši na dol. zemi, v Nadlaku, pričinením pána farára Dan. Zajaca, pamiatku pokrestančenia Slovákov v nedelu dña 5 jul. príkladne nábožným spôsobom zasvätili, svedectvom toho je horlivá obetivost pána Mat. Benčík-a, hospodára v Nadlaku, ktorý $k$ oslave tejto pamiatky nový, 1.600 r. zlatých hodný zvon obetoval. Sláva tejto šlachetnej duši slovenskej! ale sláva i všetkým ostatným rodákom, ktorí sa v nábožnej pamiatke obrátenia predkov našich na vieru krestanskú jako tak zúčastnili!“" (Tisícročné jubileum pokrestančenia Slovanov 1863, 213).

6 "Či nemáme prjklad na býwaleg nasseg matke cirkwi nadlackeg, ktorá pamiatku túto $k$ welkeg radosti horñozemského slowenska, prwá w békěšskom senioráte swätila, swätila i s ginými statisíc krestanmi na poswätnom Welehrade? Budú nás obwiňowat z katoljctwa, lebo že Ciryll a Method sa swatj katoljcki, a wrag my lutheráni čo s takými máme? A či božjm rjzenjm katoljctwo prweg nepowstalo, aby z neho pógst' mohlo nasse ewangelictwo? či w národnosti nasseg nie sme wsseci bratia? či wsseci krestania nemagú spoločnú históriu?" (Kutlík 1863, 4). Materiál k obom poznámkam nám poskytol prof. PaedDr. Miroslav Kmet', PhD.

7 Valentová 2016.

8 Autori nám zároveň prezradili aj iný motív názvu časopisu - domnievajú sa, že Cyril a Metod prechádzali cestou zo Solúna do Nitry aj okolím dnešnej Vojlovice. Pamiatku a význam sv. Cyrila a Metoda farári pripomínajú minimálne raz v roku - 5. júla (respektíve v najbližšiu nedelu) - vo všetkých evanjelických 
spolkové a iné súvislosti sv. Cyrila a Metoda s rímskokatolíckymi Slovákmi v Mad’arsku obsahuje knižná publikácia I. Klauszovej-Fúzikovej Kristus žije v dejinách cirkvi. Spomína aj také aktivity, napríklad púte na Slovensko a práve kvôli cyrilo-metodskej tradícii aj do Nitry, s akými sme sa na iných miestach stretli len zriedka. ${ }^{9}$ Okrajovo sa o sv. Cyrilovi a Metodovi zmieňuje aj Emil Vontorčík, ktorý v rozsiahlom historickom diele pripomína ich prínos pre obyvatelov dnešného Slovenska, ale aj pre východných a južných Slovanov v kontexte ich školy a rozvinutej náboženskej a filozofickej terminológie. ${ }^{10}$ Podrobne opisuje dejinné udalosti, ktoré predchádzali stahovaniu Slovákov na Dolnú zem. Dotvárajú obraz o príčinách, prijímajúcom priestore imigrácie v jednotlivých dolnouhorských stoliciach, o konfesionálnej príslušnosti kolonistov. Všetky formovali ich hodnotové orientácie vrátane vztahu ku krestanstvu a cyrilo-metodskej tradícii.

$\mathrm{Na}$ základe poznatkov z terénnych výskumov a heuristiky sme schopní reflexie porovnávat' v jednotlivých štátoch aj na úrovni konfesionálnej príslušnosti, analyzovat', interpretovat a syntetizovat.

\section{Reflexie sv. Cyrila a Metoda u Slovákov v Chorvátsku}

V Chorvátsku kult sv. Cyrila a Metoda bol rozšírený od stredoveku (Kindlerová 2013, 29-39; Mihaljević 2017, 190-197). Slováci kolonizovali územie dnešného Chorvátska od 1. tretiny 19. storočia. Rímskokatolíci, prevažne z Kysúc, osídlovali dovtedy nevyužívanú zalesnenú krajinu a dopĺňali existujúce farnosti s chorvátskym bohoslužobným jazykom. Na rozdiel od riedko osídlenej Vojvodiny, kolonizovanej bezprostredne po skončení tureckej expanzie v dôsledku spoločenskej a ekonomickej situácie v hornom Uhorsku takmer výlučne evanjelickým obyvatel'stvom, cirkev nepôsobila polarizačne MY/ONI, ale zjednocujúco a dodnes sa podiela na urýchlovaní etnickej asimilácie. Niekolko evanjelických komunít bolo dosídlených zo susednej Báčky a zo Sriemu po absolvovaní viacerých kolonizačných etáp (Čukan et. 2017, 19-272). V týchto diferentných kontextoch treba chápat aj vztah Slovákov k cyrilo-metodskej tradícii. V základných školách s vyučovacím jazykom slovenským, respektíve s vyučovaním slovenského jazyka, sú solúnski bratia stručne spomínaní v súvislosti s vytvorením hlaholiky ako základu slovanskej písomnosti a s ich christianizačnou misiou v Nitre/na Vel'kej Morave. V katolíckom kalendári je sv. Cyrilovi a Metodovi venovaný 5. júl ako sviatočný deň. $\mathrm{V}$ rámci svätých omší ich chorvátski katolícki farári spomínajú najmä v niekolkých farnostiach, ktoré sú podla nich pomenované (napr. Župa sv. Ćirila i Metoda u Osijeku). Vzhladom na používanú latinku a prevládajúce rímskokatolícke vierovyznanie majoritného obyvatel'stva (aj príslušníkov prevažnej väčšiny slovenských spoločenstiev) ich Chorváti vnímajú skôr ako svätých, bližších pravoslávnym Srbom a národom s východným obradom a s cyrilikou. Slovenskí rímskokatolícki veriaci sú súčastou chorvátskych farností, bohoslužobným jazykom je chorvátčina a zdielajú hodnoty všeobecne prijímané vo svojej súčasnej vlasti. Vierovyznanie v nich neposilňuje etnokultúrnu osobitost', nepôsobí etnodiferencujúco/národno-emancipačne ako u evanjelikov v obklúčení iných náboženstiev. Vzhladom na geopolitickú situáciu v ostatných desatročiach nie je príliš pertraktovaná ani slovanská vzájomnost'.

Slovenské inštitúcie v Chorvátsku nevenujú pozornost̉ sv. Cyrilovi a Metodovi. Rozsiahla je činnost’ miestnych organizácií Matice slovenskej a slovenských kultúrno-umeleckých spolkov, ktoré sú zväčša vedené/orientované na zachovávanie a rozvíjanie folklórnych tradícií. Výnimkou

cirkevných zboroch. Sú tak vo vedomí všetkých generácií vojvodinských evanjelikov - príslušníkov slovenskej národnosti.

9 Klauszová-Fúziková 2016. Autorka sa sprostredkovane dozvedela o našom záujme a nezištne nám poslala publikácie pre našu potrebu aj do univerzitnej knižnice.

10 Vontorčík 2020. 
je miestna organizácia Matice slovenskej v Lipovlanoch. ${ }^{11}$ „Výlučne matičným podujatím je Deň sv. Cyrila a Metoda, ktorý sa organizuje 5. júla v slovenskom etnodome. Zúčastňujú sa ho rodičia s det’mi, súčastou programu je odborná prednáška o sv. Cyrilovi a Metodovi, vystúpenie speváckeho zboru Líra a posedenie pri občerstvení. V roku 2016 sa uskutočnil 4. ročník podujatia“ (Čukan et al. 2017, 233).

Ak sa príležitostne uskutočňujú návštevy Nitry, ktorá je s vierozvestcami spätá, je len na individuálnej, súkromnej báze. Podla vyjadrenia vedúcej predstavitel'ky slovenskej kultúrnej inštitúcie v Našiciach „[...] je v prvom rade treba uchovávat existujúce tradície, a ani na to nestačíme“. Dva slovenské evanjelické a. v. cirkevné zbory (Ilok a Solany) sv. Cyrila a Metoda pravidelne spomínajú obidvoch vierozvestcov 5. júla pri príležitosti bohoslužieb, kde vyzdvihujú ich význam pre vznik slovanskej a slovenskej písomnosti a rozvoja vzdelanosti. Evanjelická cirkev v Chorvátsku ich vo svojej agende nemá. „Je to na vôli farára. Nemala som nikdy odvahu o nich hovorit na vyššej cirkevnej úrovni, aby ma nevnímali ako osobu, ktorá zo Srbska niečo forsíruje. Ale slovenskí evanjelici vedia, čo znamenajú pre Slovákov a pre cirkev" (Svetlana Vojnićová-Feldiová).

\section{Reflexie sv. Cyrila a Metoda u Slovákov v Srbsku}

Vojvodinskí Slováci tvoria najpočetnejšie dolnozemské slovenské spoločenstvo. Do Báčky, Banátu a do Sriemu prechádzali v rámci jednotlivých kolonizačných vín z územia dnešného Madarska, alebo priamo z hornouhorských stolíc. S vidinou náboženskej slobody a získania vlastnej pôdy išli na čele so svojimi kňazmi na ludoprázdne, Osmanmi spustošené územia a zakladali vlastné osady, stavali si kostoly, formovali kultúrnu krajinu. Pre slovanských Srbov, prichádzajúcich spoza vojenskej hranice, boli na vyššej vzdelanostnej, aj hospodárskej úrovni, preto si ich vážili, ako majorita ich rešpektovali a vzájomne boli tolerantní k svojej viere (Sirácky 1980, 66-70; porovnaj s: Michalík 2015, 58-62 a Kmet' 2012, 28-30).

Slováci vedia o sv. Cyrilovi a Metodovi najmä zo školy, lekcie sú v základných školách s vyučovacím jazykom slovenským, respektíve s vyučovaním slovenského jazyka, na Gymnáziu v Báčskom Petrovci, Kovačici, aj na Katedre slovakistiky Filozofickej fakulty Univerzity v Novom Sade. Ale poznajú ich aj z kultúrnych inštitúcií a predovšetkým z evanjelických kostolov. „Pospolitý vojvodinský Slovák si uvedomuje, že sú to významné osobnosti pre naše náboženstvo a kultúru, pre zachovanie náboženskej a kultúrnej identity a slovanskej spolupatričnosti“ (Vladimír Valentík).

V roku 2006 inštalovali pred Študentským domovom krála Aleksandra v belehradskom Parku Cyrila a Metoda sochu Cyrila a Metoda, identickú ako v Ochride - dielo macedónskeho sochára Tome Serafimovského. Mestská knižnica v Pančeve nesie meno sv. Cyrila a Metoda. V Novom Sade je pravoslávny chrám sv. Cyrila a Metoda. V súvislosti s pamiatkou na sv. Cyrila a Metoda sa v roku 2019 stal Deň slovanskej písomnosti a kultúry štátnym sviatkom, ktorý pripadá, podla starého cirkevného kalendára, na 24. mája. Napriek tomu, že v popredí stojí Rastko Nemanjič, Sveti Sava, zakladatel’ autokefálnej srbskej pravoslávnej cirkvi a srbského písomníctva, sa 24. mája 2020 napriek pandemickej situácii uskutočnila beseda na počest’ sv. Cyrila a Metoda v belehradskom kláštore Rakovica, kde je pochovaný aj patriarcha Pavle. Pozvaný bol napríklad aj velvyslanec

11 Lipovlany v Sisacko-moslavinskej župe sú od ostatných slovenských spoločenstiev značne izolovaní, no lokálne spoločenstvo tvoria spolu s Chorvátmi, Čechmi a Ukrajincami. Spolužitie s veriacimi východného obradu, pre ktorých pôsobí vierovyznanie etnodiferencujúco/etnozjednocujúco má vplyv aj na vedomie slovenskej časti miestnej komunity. Zdôraznit treba aj výrazné kultúrne aktivity MO MS a Kultúrno-umeleckého spolku Lipa, ktorý pravidelne organizuje kultúrne podujatia a udržiava družobné stretnutia s viacerými dedinami na Hornej Nitre. Časté kontakty so starou vlastou formujú aj vedomie ich spolupatričnosti s materským národom. 
Slovenskej republiky v Srbsku a aktívne vystúpili predstavitelia slovenských vedeckých a kultúrnych kruhov. Organizuje ju Združenie spisovatelov Srbska od roku 2011 v Belehrade aj v iných mestách. Cez Srbsko sa plánuje viest’ aj Európska kultúrna cesta sv. Cyrila a Metoda (Peterka 2016, 116).

Na báčskopetrovskom gymnáziu sa v medzivojnovom období konali večierky, venované solúnskym bratom, po založení MS sa v slovenských vojvodinských spoločenstvách konali prednášky o sv. Cyrilovi a Metodovi. Aktivity po 2. svetovej vojne ustali, ale od roku 2000 MO MS v Báčskom Petrovci spoločne s evanjelickým a. v. cirkevným zborom začali organizovat Cyrilo-metodský večierok. ${ }^{12}$ Odvtedy sa koná pravidelne a zúčastňujú sa na ňom aj predstavitelia spomenutého novosadského pravoslávneho kostola. Vo vojvodinských spoločenstvách majú príslušníci národnostnej menšiny možnost’ sledovat' slávnost’ v slovenskom vysielaní RTV Novi Sad, prípadne na sociálnych siet̉ach. Iné kultúrne inštitúcie v Srbsku fungujúce na slovenskom etnickom princípe (okrem evanjelickej cirkvi) cyrilometodskú tradíciu nereflektujú. ${ }^{13}$ Zjednotený kovačický cirkevný zbor si na službách Božích, v najbližšiu nedelu k 5. júlu, každoročne pripomína pamiatku sv. Cyrila a Metoda v súvislosti s krestanstvom, písomníctvom, vzdelanostou a slovanskou vzájomnostou. Cirkevný zbor z Kovačice ( $v$ minulosti označovaný ako Kovačica II) navštívil začiatkom júla 2012, pri príležitosti spomienok na sv. Cyrila a Metoda, evanjelický a. v. cirkevný zbor v Senici. Zúčastnil sa aj spomienkových Bohoslužieb na hrade Branč. V hostitel'skom Myjavskom senioráte vystupoval kovačický cirkevný spevokol aj mládežnícke hudobné kvarteto. Silbašská evanjelická farárka Jasmína Kotasová-Medvedová označila v spomienkovej kázni sv. Cyrila a Metoda ako mužov viery a vzdelania. Vo Vojlovici existuje popri každoročne sa opakujúcej kázni aj vyššie spomenutý časopis Proglas, hoci so solúnskymi bratmi a ich dielom obsahovo nekorešponduje. V Starej Pazove je po sv. Cyrilovi a Metodovi pomenovaná najdlhšia ulica ${ }^{14}$, v evanjelickom chráme si ich pripomínajú súčasne s významom majstra Jána Husa (6. júl), aj pri rôznych cirkevných a ekumenických oslavách. Napríklad pri spomienke na prvého biskupa Adama Vereša vyzval vladyka sriemsky Srbskej pravoslávnej cirkvi k slovanskej vzájomnosti aj prostredníctvom pamiatky sv. Cyrila a Metoda. Známy kovačický insitný maliar Ján Glózik namaloval pri príležitosti 1150. výročia príchodu sv. Cyrila a Metoda na Vel'kú Moravu obraz s odrazom cyrilometodskej tradície. Vystavený je na Ministerstve zahraničných vecí a európskych záležitostí SR v Bratislave, na čo je autor hrdý.

12 Z príhovoru Jána Vidu, zborového farára v Báčskom Petrovci, v evanjelickom chráme Ku sviatku Cyrila a Metoda a Majstra Jána Husa (júl 2020): „Krestanské zhromaždenie, bratia a sestry v Pánovi Ježišovi Kristovi, práve v dnešný deň 5. júla si pripomíname pamiatku slovanských vierozvestov Cyrila a Metoda, ktorí roku 863 prišli z Byzantskej rísé, z mesta Solúnu, Tesaloniké na Velkomoravskú rišú. Pre našich predkov znamenali velký prínos, ako pre náboženský, tak aj pre kultúrny život. Zostavili písmo a preložili Bibliu do staroslovienčiny. Pripravovali kňazov pre kňazskú a pastorálnu službu, vyučovali ludí krestanským pravdám a oslobodzovali ich myslenie od povier. $V$ dnešný deň predovšetkým myslíme na vzácny prínos dôležitej skutočnosti, že našim predkom bolo umožnené počúvat' a čitat slovo Božie v zrozumitelnej, materinskej reči. [...] Biblia, ktorú nám v zrozumitelnej reči priniesli Cyril a Metod, tá Biblia, o čistú interpretáciu ktorej sa tak velmi zaslúžil Majster Ján Hus, je pre nás osobne vzácnym pokladom. Spomienka na nich nás zaväzuje, aby táto kniha bola aj dnes pre nás živou knihou."

13 Anna Páliková-Kunčáková, kazatelka Evanjelickej metodistickej cirkvi v Kysáči, nám okrem iného napísala: „Niektoré evanjelické cirkevné zbory mávajú bohoslužby na ten deň. No a my budeme. Predsavzali sme si, že prvá júlová nedela bude im venovaná. Pri bohoslužbách som spomenula Vaše otázky a velmi horlivo ludia odpovedali aj vedeli, kto sú Cyrila Metod [...] pod kazatelnicou sa vzdelávame duchovne, ale i v slovenčine."

14 K zastúpeniu cyrilo-metodských patrocínií na Slovensku pozri: Nemčíková et al. 2020. 


\section{Reflexie sv. Cyrila a Metoda u Slovákov v Rumunsku}

V každom slovenskom spoločenstve aj v každom štáte je zachovávanie slovenského kultúrneho dedičstva špecifické, lebo všade existuje a rozvíja sa v neopakovatelných podmienkach. Slováci v Rumunsku žijú v prostredí neslovanského románskeho národa, ktorý je prevažne pravoslávneho vierovyznania s prajnou menšinovou politikou (podobne ako v Srbsku). V parlamente majú Slováci svoje zastúpenie a Demokratický zväz Slovákov a Čechov v Rumunsku (DZSČR) je v rámci štátnej správy aj samospráv akceptovaným partnerom (Čukan et. al. 2019, 375-377).

Pôvodné slovenské menšinové spoločenstvá boli evanjelického aug. vyznania, sídla mali situované na juhozápade územia $\mathrm{v}$ Aradskej oblasti a v Temešskom Banáte. Intenzívne príbuzenské, konfesionálne a ekonomické kontakty udržiavali so slovenskými spoločenstvami rovnakého vierovyznania v Békešskej župe a v srbskom Banáte. Od konca 18. storočia expandovalo do oblasti Sedmohradského rudohoria (Bihorská a Salajská župa) slovenské rímskokatolícke obyvatel'stvo $\mathrm{z}$ hornouhorských žúp, veriaci si vytvorili farnosti na slovenskom etnickom princípe a v takýchto podmienkach existujú dodnes. Od 60. rokov 20. storočia postupne dosídlujú pôvodné evanjelické spoločenstvá na juhozápade a miešanými manželstvami revitalizujú slovenské komunity, ktoré nadobúdajú multietnický a multikonfesionálny charakter (pravoslávni Rumuni, evanjelickí a rímskokatolícki Slováci, mad’arskí katolíci, gréckokatolícki Rusíni). Formuje sa synkretická slovenská kultúra: pôvodná evanjelická s prvkami nížinnej polnohospodárskej a rímskokatolícka s charakterom horskej - drevorubačsko-pastierskej, baníckej a sklárskej. Bohoslužobným jazykom evanjelikov aj katolíkov v Bihore a Salaji zostala slovenčina, kolonizovaní katolíci na juhozápade majú prevažne madarských farárov a bohoslužobným jazykom je rumunčina, prípadne madarčina. Cyrilo-metodská tradícia v kostoloch so slovenskými kňazmi bez rozdielu vierovyznania sa obnovuje v rámci pamiatky výročia príchodu sv. Cyrila a Metoda na Velkú Moravu kontinuálne, hoci s rôznou intenzitou a obsahom/významom. Cirkev pôsobí etnozjednocujúco v zmysle slovenskej aj slovanskej vzájomnosti, katolícki kňazi viac akcentujú náboženský význam. Napríklad vo Vukovej (podobne Cipár, Temešvár), kde je aj katolícka farnost̉ a nepravidelne sem dochádzajú madarskí farári, si sv. Cyrila a Metoda nepripomínajú, hoci sú v cirkevnom kalendári (Čukan et. al. 2019, 345).

Deti so slovenskou etnickou identitou, respektíve s vedomím slovenskej etnickej príslušnosti, sú edukované v slovenskom jazyku, respektíve majú možnost̉ navštevovat' hodiny slovenčiny v rámci základných škôl, na slovenských lýceách v Nadlaku a Bodonoši i v rámci univerzitného štúdia slovenčiny v Bukurešti. O sv. Cyrilovi a Metodovi sa učia žiaci 6. triedy v rámci predmetu Dejiny a tradície Slovákov v Rumunsku, v 9. ročníku v súvislosti s problematikou Slovanov. Rozsah a zameranie učiva často závisí od pedagóga, podobne ako na hodinách náboženstva (Pavel Hlásznik).

Organizácie DZSČR cyrilo-metodskú tradíciu formálne nereflektujú, nepodielajú sa na organizovaní návštev Cyrilo-metodských slávností v Nitre. V Sedmohradskom rudohorí je ich činnost’ výrazne prepojená s aktivitami rímskokatolíckej cirkvi a sv. Cyril a Metod sú v povedomí Slovákov najmä v náboženskom kontexte. Kňazi ich misiu a význam pripomínajú v deň ich sviatku (5. júl). Odlišná je situácia v Novej Hute. Do roku 1974 bol rímskokatolícky kostol zasvätený Nanebovzatiu P. Márie, v tom roku bolo z iniciatívy farára Vavrinca Ferenčíka patrocínium zmenené na sv. Cyrila a Metoda. Vo všetkých slovenských farnostiach v Sedmohradskom rudohorí sa 5. júl svätí ako cirkevný sviatok a deň pracovného pokoja. V nasledujúcu nedelu sa na Novej Hute koná odpust, ktorému predchádzajú náležité prípravy v kostole, na fare aj v rodinách veriacich. Považovaný je za najväčší odpust v regióne. Príbuzní z miest, zo vzdialenejších regiónov Rumunska aj zo zahraničia si plánujú dovolenky tak, aby tento sviatok prežili doma v kruhu najbližších. Účastníci zo širokého slovenského katolíckeho okolia sa počítajú na stovky, autobusmi organizovane prichádzajú veriaci 
bez ohladu na príbuzenské väzby. Z vopred určeného zhromaždiska sa skupiny s vyzdobeným krížikom na čele, ktorý nesie dieta, presúvajú ku kostolu za spevu piesní z katolíckeho spevníka. Je to manifestácia náboženská a zároveň etnozjednocujúca, slovenská, hoci si to účastníci v danej chvíli neuvedomujú. Z kapacitných dôvodov sa sv. omša koná na nádvorí, spravidla dvakrát - predpoludním a na poludnie. V rodinách sú velké hostiny. Na organizovanej účasti pútnikov z iných farností sa podla potreby podiela aj DZSČR (Čukan et. al. 2019, 171-186).

Evanjelickí farári spájajú v náboženských súvislostiach Deň Cyrila a Metoda s pamiatkou na Majstra Jána Husa (6. júl). Zdôrazňujú však aj iné rozmery; prínos vierozvestcov pre lud: vznik zrozumitelného bohoslužobného jazyka ako základu slovanského písomníctva a vzdelanosti, preklad Biblie, slovanskej vzájomnosti, slovenskej národnej jednoty a spolupatričnosti s materským národom.

\section{Reflexie sv. Cyrila a Metoda u Slovákov v Mad’arsku}

Slovenskí kolonisti obsadzovali územie dnešného Madarska bezprostredne po ústupe Turkov. Severojužným smerom postupovalo obyvatelstvo za slobodou vierovyznania aj kvôli možnosti získat pôdu a hospodárit vo vyplienenej krajine. V členitom severozápade a v Zadunajsku žijú dodnes najmä rímskokatolíci, na rovinách medzi Dunajom a hranicou Rumunska prevažne evanjelici aug. vyznania. Je to len orientačné členenie, vytýčit’ ostrejšie kontúry je nemožné. Migranti z hornouhorských stolíc odchádzali bez vyhraneného vedomia etnickej príslušnosti, po rakúsko-uhorskom vyrovnaní čelili mad’arizácii, ktorá sa dodnes prejavuje vo výraznom stupni etnickej asimilácie. Vztảa majoritného neindoeurópskeho národa k príslušníkom slovenských minoritných spoločenstiev a ich súčasné reakcie sú obojstranne poznačené historickými skúsenostami a snahou nevydelovat’ sa v spoločnom štáte od svojich spoluobčanov. Na rozdiel od Chorvátska, no najmä Srbska a Rumunska sú komunikačné zručnosti v nárečiach slovenského jazyka na nižšej úrovni. Jazyk je jeden z podstatných znakov národa a s jeho absenciou je na ústupe etnická identita a dokonca aj vedomie pôvodu. V tejto súvislosti možno na úrovni zachovávania slovenského jazyka vo všeobecnosti konštatovat postupne zanikajúcu revitalizačnú funkciu evanjelickej aj katolíckej cirkvi. Katolíci dlhodobo používajú takmer výlučne mad’arský bohoslužobný jazyk, evanjelické bohoslužby v slovenskom jazyku sa stávajú čoraz zriedkavejšími. Dôvodom je aj slabšia znalost’ slovenského jazyka, respektíve jeho neznalost’ u najmladšej a strednej generácie (Čukan Michalík - Pluhár 2018, 161-211). Ak mad’arskí katolícki duchovní spomenú Cyrila a Metoda, tak spolu so sv. Štefanom a ich christianizačným významom. V kostole sv. Klementa v Kestúci vysvätili v roku 1985 mozaiky sv. Cyrila a Metoda, „[...] ktoré chcú zachovat’ a posilnit’ cyrilometodské dedičstvo $v$ Slovákoch tejto obce aj na začiatku tretieho tisícročia a odovzdat'úctu sv. Klementa, ako aj Cyrila a Metoda d’alším generáciám" (Klauszová-Fúziková 2016, 124).

V 90. rokoch 20. storočia „z potreby doby a z potrieb slovenských veriacich $v$ Madarsku vznikol prvý slovenský ekumenický náboženský časopis sv. Cyril a Metod [...] so zámerom obnovit’v tunajších Slovákoch povedomie príslušnosti k duchovným koreňom nášho krestanstva a kultúry [...]“ (Klauszová-Fúziková, 2016, 139).

Slovenskí katolíci v Budapešti využili prítomnost̉ pátra Jakuba Rafaela zo Slovenska a v Kostole sv. Jozefa usporiadali v júli 2020 spomienkovú sv. omšu. Kazatel’ pripomenul slovanských vierozvestcov, ich význam pre Slovákov v Mad’arsku a pre slovanskú vzájomnost'.

V evanjelickom kalendári je označený 5. júl ako deň Cyrila a Metoda. Závisí od evanjelického farára, či tento sviatok reflektuje a v rámci kázne spomenie ich pamiatku, ako je to každoročne napríklad v Sarvaši a v tých cirkevných zboroch, do ktorých prichádza putujúca farárka na dôchodku Alžbeta Nobiková. Študenti navštevujú slovenské bohoslužby len výnimočne, a tak si vedomost’ 
o cyrilo-metodskej tradícii v rámci cirkvi neobnovujú. Ak nemajú vedomie slovenskej etnickej príslušnosti, myšlienky o spolupatričnosti Slovákov a o slovanskej vzájomnosti by ani nechápali.

Slovenčina v základných školách je v podstate na úrovni výučby volitelného cudzieho jazyka. Komunikovat v slovenskom jazyku sú schopní len niekol'kí študenti v triedach slovenského gymnázia v Békešskej Čabe, ktorí sú v rodinách aj na verejnosti socializovaní v kultúrnych vzoroch majoritného národa. Cyril a Metod sú v rámci vyučovania spomínaní v súvislosti s písomníctvom a christianizáciou. S ich tradíciou sa oboznamujú aj pri príležitostných výstavách, prípadne v rámci exkurzií na pamätné miesto do Blatnohradu. Spomenút možno napríklad výstavu o živote a diele Cyrila a Metoda, ktorá bola inštalovaná v Békešskej Čabe aj v niektorých dalších mestách so slovenskou národnostnou menšinou v roku 2015.

Podobne, ako v Srbsku a v Rumunsku, aj mad’arskí Slováci majú svoje zastúpenie v parlamente. Na tejto pôde slovenský zástupca príležitostne pripomína sv. Cyrila a Metoda v súvislosti so vznikom slovanského jazyka, písomnosti a viery v Panónii, aj ako spolupatrónov Európy a základ porozumenia medzi Madarmi a príslušníkmi slovanských národov (s príhovorom podobného obsahu vystúpil v mad’arskom Národnom zhromaždení v Budapešti 2. júla 2018 slovenský parlamentný hovorca Anton Paulik) (Anton Paulik v parlamente o sv. Cyrilovi a Metodovi 2018).

Zákon 241/1993 Z. z. upravuje, že 5. júl je v Slovenskej republike štátnym sviatkom Cyrila a Metoda a zároveň Pamätným dňom zahraničných Slovákov. V reakcii na tento zákon Celoštátna slovenská samospráva v Madarsku v roku 1996 rozhodla, že 5. júl ustanoví ako najväčší sviatok slovenskej národnostnej menšiny v Mad’arsku (Anton Paulik v parlamente o sv. Cyrilovi a Metodovi 2018). Deň Slovákov v Mad’arsku sa usporadúva každoročne v prvú júlovú sobotu, pri príležitosti Dňa sv. Cyrila a Metoda, vždy v inom, Slovákmi obývanom regióne. Súčastou osláv býva putovná výstava o živote a diele vierozvestcov a ekumenická pobožnost', v rámci ktorej sa pripomína význam spolupatrónov Európy. Ak sme $\mathrm{k}$ našim respondentom smerovali otázku o vedomí cyrilo-metodskej tradície u Slovákov v Mad’arsku, odpoved’ bola nasledovná: „O Cyrilovi a Metodovi, o ich význame pre vieru, vzdelanost' a slovanskú spolupatričnost' vie každý, kto prichádza na oslavy Dña Slovákov v Mad’arsku. Každý rok sú na inom mieste a kto chce, príde a vie“ (Tibor Mótan).

Celoštátna slovenská samospráva v Mad’arsku a Slovenský inštitút v Budapešti s podporou Slovenskej republiky postavili v Blatnohrade (mad. Zalavár) súsošie sv. Cyrila a Metoda, kde sa každoročne organizuje zájazd/pút Slovákov z Budapešti so spomienkovým príhovorom, kultúrnym programom a s kladením vencov.

Z inštitúcií, fungujúcich na slovenskom etnickom princípe, je potrebné spomenút aktivity Výskumného ústavu Slovákov v Békešskej Čabe. Popri terénnych výskumoch a dokumentácii kultúrneho dedičstva Slovákov v Mad’arsku organizuje vedecké konferencie a Národopisné výskumné tábory. Problematiku cyrilo-metodskej tradície sme v jeho aktivitách nezaregistrovali, no $\mathrm{v}$ rámci výskumov sme získali aj niektoré údaje a inšpirácie k príprave tejto štúdie.

\section{Záver}

V rámci mapovania a hodnotenia kultúrneho potenciálu dolnozemských Slovákov sme zaznamenali množstvo prejavov kultúrneho dedičstva, ktoré nesúviseli s prioritným vedeckovýskumným zámerom. Popri problematike historickej interpretácie stahovania Slovákov na Dolnú zem, najrôznejších prejavov dekorativizmu, vplyvu cirkvi a vierovyznania na formovanie špecifických kultúrnych vzorov či metodológie výskumu sa objavili aj indície o význame cyrilo-metodskej tradície ako jedného z relevantných faktorov formovania hodnotových orientácií a vedomia etnokultúrnej príslušnosti. Prostredníctvom porovnávacej metódy, syntézy a autorskej interpretácie prispievame k obohateniu komplexu poznatkov kultúrnej antropológie a kulturológie, kultúrnej histórie, 
religionistiky, politológie, metodológie vedy a možno aj filozofie kultúry a iných disciplín. Reflexie cyrilo-metodskej tradície v slovenských spoločenstvách vznikali v rôznych historických, politických, legislatívnych, ekonomických, etnických, konfesionálnych a geografických súvislostiach, a preto majú diferentné prejavy. Všetky determinujúce faktory a ich dôsledky sme nezaregistrovali, alebo sme im nevenovali náležitú pozornosṫ. Potvrdzujú sa však tézy Franza Boasa o troch dimenziách kultúry, vd’aka ktorým je každá kultúra jedinečná: prvú dimenziu však chápeme podstatne širšie ako človek-prírodné prostredie; dimenziu človek-človek nemožno revidovat a tretia dimenzia je o človeku ako neopakovatelnej osobnosti s osobitými hodnotami, vnímaním a miešaním farieb, ktorá riadi aj vykonáva, a spestruje mozaiku neopakovatelnými farebnými tónmi a leskom. Preto sú reflexie sv. Cyrila a Metoda u dolnozemských Slovákov podobné, no aj diametrálne odlišné, obsahom aj formou obohacujúce. A uvedomujeme si aj to, že nami predstavený obraz reality nemusí byt vo všetkých prípadoch jej objektívnym odrazom; iní autori by možno odhalili iné súvislosti údajov, predstavili by iné interpretácie.

\section{REFERENCES}

Anton Paulik v parlamente o sv. Cyrilovi a Metodovi 2018. In Oslovma.hu: Slovák v Mad’arsku / Magyarországi Szlovák. http://www.oslovma.hu/index.php/sk/archiv/ 185-archiv-nazory/1430-anton-paulik-v-parlamente-o-sv-cyrilovi-a-metodovi.

Čukan, Jaroslav et al. 2017. Kultúrny potenciál Slovákov v Chorvátsku. Nitra.

Čukan, Jaroslav et al. 2019. Kultúrny potenciál Slovákov v Rumunsku. Nadlak.

Čukan, Jaroslav - Michalik, Boris - Pluhár, Tamás. 2018. Kultúrny potenciál Slovákov v Békešskej Čabe. In Kapitoly z minulosti a súčasnosti Slovákov v Békešskej Čabe. Békešská Čaba, 161-211.

Hetényi, Martin. 2019. Cyrilo-metodský kult a religiozita na Slovensku v 19. - 21. storočí [The Cyrillo-Methodian Cult and Religiosity in Slovakia from the 19th to the 21st Century]. In Konštantínove listy [Constantine’s Letters] 12/1, 141-158.

Ivanič, Peter - Lukáčová, Martina. 2015. Svätý Metod na misijných a diplomatických cestách (Historicko geografické súvislosti) / Saint Methodius on Missionary and Diplomatic Journeys (Historical Geographical Context). In Historický časopis 63/4, 649-659.

Kindlerová, Anežka. 2013. Cyrilometodějská úcta v Chorvatsku v 19. a 20. století. In Caritas et veritas 3, 29-39.

Klauszová-Fúziková, Ildika. 2016. Kristus žije v dedinách cirkvi. Budapest.

Kmet', Miroslav. 2012. Krátke dejiny dolnozemských Slovákov. Nadlak.

Kutlik, Ján ml. 1863. Reč Chrámová, ktorú w XI. nedelu po sw. Tr. r. P. 1863 pri sláwnweg tisjcročneg pamiatke pokrestančenia sa nassich predkov slowanských w cirkwi ew. a. w. bánhedešskej držal... Arad.

Mihaljević, Milan. 2017. Croatian Glagolitism Between the West and the East. In Konštantínove listy [Constantine's Letters] 10/1, 190-197.

Michalík, Boris. 2015. Akulturačné procesy v prostredí dolnozemských Slovákov. Nadlak.

Nemčíková, Magdaléna et al. 2020. Sv. Cyril a Metod a ich reflexia v krajine Slovenska [Sts. Cyril and Methodius and Their Reflection in the Landscape of Slovakia]. In Konštantínove listy [Constantine's Letters] 13/1, 224-236.

Peterka, Martin. 2016. Cyrilometodějská stezka jako příležitost’ pro využití a interpretaci společného evropského kultúrního dědictví [The Route of Cyril and Methodius as an Opportunity for the Use and Interpretation of the Common Euporean Cultural Heritage]. In Konštantínove listy [Constantine's Letters] 9/2, 106-118.

Sirácky, Ján et al. 1980. Slováci vo svete 1. Martin. 
Szőke, Béla Miklós. 2010. Mosaburg/Zalavár und Pannonien in der Karolingerzeit. In Anteus 31/32, 9-52.

Šusteková, Ivana. 2012. Rezíduá predkrestanských náboženských kultov v tradičnej kultúre Slovenska v prvej polovici 20. storočia. In Konštantínove listy [Constantine’s Letters] 5/1, 73-92.

Tisícročné jubileum pokrestančenia Slovanov. Pamiatka pokrestančovania Slovanov v cirkvi evanjelickej. 1863. In Domová Pokladnica. Národný slovenský obrázkový Kalendár na prestupný, 366 dní majúci rok Pána 1864. Skalica.

Tomljanovich, William Brooks. 2001. Biskup Josip Juraj Strossmayer: Nacionalizam i moderni katolicizam u Hrvatskoj. Zagreb.

Valentová, Anna Margaréta. 2016. Slovak-language Evangelical Magazines in Serbian Vojvodina. In Slovenská literatúra 63/4, 298-302.

Vontorčík, Emil. 2020. Bitka pri Viedni 1683. Stret civilizácií krestanského kríža a islamského polmesiaca. Nitra.

Zákon 241/1993 Z. z. o štátnych sviatkoch, dňoch pracovného pokoja a pamätných dňoch.

Zozulak, Ján. 2019. Zdroj hodnôt v kultúrnom živote Slovanov [A Source of Values in the Cultural Life of the Slavs]. In Konštantínove listy [Constantine's Letters] 12/1, 13-21.

\section{RESPONDENTS}

Pavel Baláž

Maria Calamarová

Pavel Hlásznik

Magdaléna Laczová

Jasmína Kotasová-Medvedová

Sandra Kralj-Vukšić

Branislav Kulík

Katarína Melegová-Melichová

Tibor Mótan

Miroslav Pap

Anna Páliková-Kunčaková

Vladimír Valentík

Ján Vida

Svetlana Vojnićová-Feldiová

prof. PhDr. Jaroslav Čukan, CSc.

Constantine the Philosopher University in Nitra

Faculty of Arts

Department of Management of Culture and Tourism

Štefánikova 67

94974 Nitra

Slovakia

jcukan@ukf.sk

ORCID ID: 0000-0002-6897-910X

WOS Researcher ID: AAM-7062-2020

SCOPUS Author ID: 56576371700 
doc. PhDr. Boris Michalík, PhD.

Constantine the Philosopher University in Nitra

Faculty of Arts

Department of Management of Culture and Tourism

Štefánikova 67

94974 Nitra

Slovakia

bmichalik@ukf.sk

ORCID ID: 0000-0002-2045-0063

WOS Researcher ID: AAL-8844-2020

SCOPUS Author ID: 57195475491 